\title{
Tehri Dam: An Engineering Marvel
}

\author{
Basistha Raj Adhikari
}

\begin{abstract}
Despite repeated controversy over implementing high dams in the Himalayan region, the Government of India has completed the first stage of Tehri Dam hydroelectric project with power generating capacity of 1,000 MW. Being the third dam of its kind after Bhakra and Pong in India, Tehri Dam has faced several social, legal and engineering challenges. Most of them may be lessons for the whole Himalayan region including Nepal. The Tehri Dam Project was initiated in 1970s with technical support from the USSR. Later, with the establishment of Tehri Hydro Development Corporation, the project was resumed with new dimensions to be developed in three stages: Tehri Dam Project with 1,000 MW in Stage 1, Koteshwar Power Plant with 400 MW capacity in Stage-2, and Tehri Pump Storage Plant with 1,000 MW capacity providing altogether 2,400 MW of clean hydro electric energy in Stage-3. The first stage project was commissioned in 2006 while the second stage is under construction. The major outcome of the Tehri Dam Project is its successful implementation of rehabilitation and resettlement plans through the establishment of the New Tehri town in the Garhwal hills and adjacent areas. This article shares the technical innovation of Tehri Dam Project from socio-engineering perspective.
\end{abstract}

Key words: Tehri Dam Project, storage hydropower project, rehabilitation and resettlement, India

\section{Introduction}

most controversy-ridden Tehri High Dam is in reality Aan engineering marvel of modern India that provides new horizons for implementing high dams in Himalayan region. The generation of clean hydro-energy from the reservoir built at Bhagirathi river represents, duration wise, one of the longest ever constructed projects of India. Despitethedelayedimplementationinaddressingtheissues of environment, potential seismic hazards, rehabilitation and resettlement, the Government of India has boldly shown its commitment towards the execution of high dams in Himalayan region and has made a breakthrough in an amicable solution of the debate on large dams. Being the third high dam in Himalayan region after Bhakra and Pong in India, Tehri Dam was confronted with several social, legal and engineering challenges, most of which may be lessons for the whole Himalayan region including Nepal. In the wake of the New Nepal's commitment to generate $10,000 \mathrm{MW}$ of electricity in 10 years, it is worthwhile to share the engineering expertise of Tehri Hydroelectric Power Project, which has commissioned its first stage development in 2006.

\section{Project Initiation}

The Tehri Dam Project is located in Bhagirathi river, a major tributary of Ganga river, about $80 \mathrm{~km}$ upstream from Rishikesh in Garhwal District of the newly formed northern state of Uttarakhand (Figure 1). Based on the preliminary investigation of 1961, the project was planned and designed with power generating capacity of only $600 \mathrm{MW}$ in 1972. After the detailed feasibility study, the project construction was started in 1978, but due to issues of environment and resettlement the project was delayed despite ongoing administrative, social and environmental activities. In 1986 the Tehri Dam Project was agreed to be constructed by the USSR on turnkey basis with its technical and financial assistance. Due to political changes in the USSR, Russian withdrew its support to the high dam project and the Government of India took the initiation, to resume the project with its own financial and technical resources. At first, the Irrigation Department of Uttar Pradesh (UP) took the lead role to implement the project in the changed context, as the project envisaged to provide additional irrigation in UP.

Formation of Tehri Hydro Development Corporation (THDC) in 1988, a joint undertaking of the Central Government of India and the Government of UP, was a major milestone in the implementation and development of the Tehri Dam Project. The share of equity investment is 3/4ths for the Central Government and 1/4th for the State Government in the hydropower component, while the irrigation component was agreed to be financed solely by the State Government of UP.

Local activists and environmentalists filed court cases against the project execution and THDC. In the mean time, the project was revised in 1990 from the original $600 \mathrm{MW}$ reservoir project to a new 2,400 MW multipurpose project to be developed in three stages at the time when conditional clearance was given by the Ministry of Environment and Forest to continue the project.

The first stage development is the Tehri Dam and Hydropower Plant situated just downstream of old Tehri town and the second stage development is the Koteshwar Dam and Hydropower Plant being constructed at about $22 \mathrm{~km}$ downstream of Tehri main dam. The third stage development of the THDC is the Tehri Pump Storage Plant, which is still in planning stage. The Tehri Dam and hydropower plant has an installed capacity of 1,000 MW, which is in operation since 2006, while the Koteshwar Dam is under construction with the aim to generate $400 \mathrm{MW}$ of power by 2010. The Tehri Pump Storage Plant aims to lift the water from lower Koteshwar Dam to upper Tehri Dam 


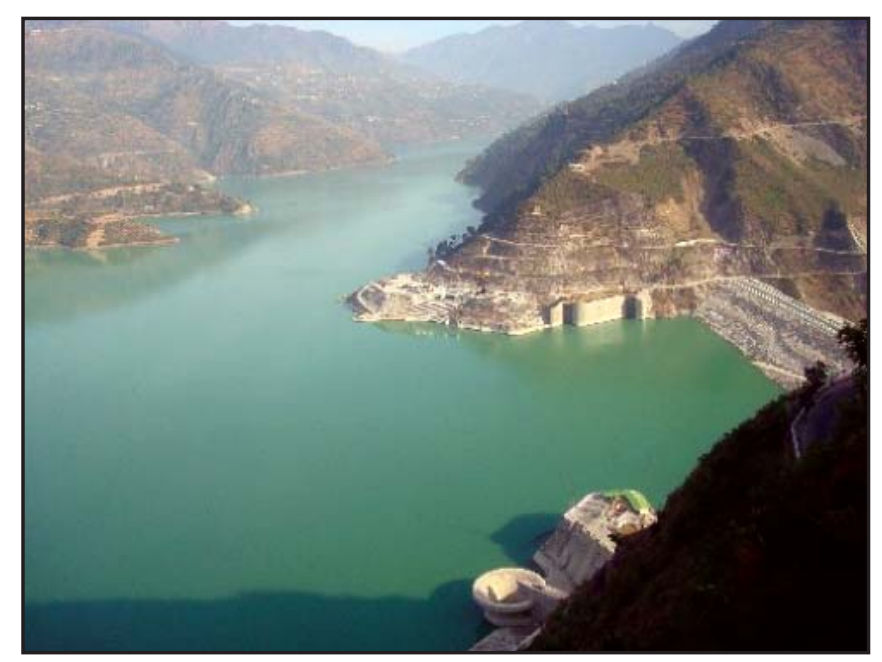

Photo 1. Tehri Reservoir and Dam

during off peak hours and generate 1,000 MW of power during peak hours. The main Tehri Dam is constructed about $40 \mathrm{~km}$ upstream of Devprayag, whileKoteshwar Dam is situated at $22 \mathrm{~km}$ downstream of the main Tehri Dam. Being a multipurpose project, the Tehri Dam Project aims to irrigate 0.874 million hectors of land in Uttar Pradesh and to provide drinking water supply to Delhi and UP in addition to power generation. The geographical locations of these projects are in Mahabharat range (similar to the Budhi Gandaki, West Seti and Arun Valley sites of Nepal).

\section{River Bhagirathi}

River Bhagirathi originates from Gangotri glacier at an altitude of 7,010 meters and traverses about 200 kilometers to its confluence with Bhilganga, where Asia's tallest Tehri Dam is walled up. The average annual flow of the Bhagirathi is 258 cumecs (similar to the Sunkoshi river at Pachuwaghat and Kaligandaki river at Seti Beni, in Nepal). After Tehri, the Bhagirathi traverses $30 \mathrm{~km}$ through Koteshwar to its confluence with the Alaknanda at Devprayag; henceforth, the river is named the Ganga and flows through Rishikesh and Hardwar, major holy places for Hindus. Of the total annual water yield of 8,135 million cubic meters of Bhagirathi, about one third (i.e., 2,615 million cubic meters) is being stored in the Tehri main reservoir. The Tehri reservoir is designed to reserve the monsoon flow from July to September when river stages are high enough, and to utilize it to generate $6,200 \mathrm{GWh}$ of energy mostly during peak hours. The main reservoir has a surface area of 42 square kilometers (Photo 1) at full reservoir level of $830 \mathrm{~m}$, which submerged the old Tehri town along with 96 villages in Garhwal region of Uttarakhand.

\section{Tehri Dam}

The main Tehri Dam is engineered earth and rock material in a unique height of 261 meter, making it the $8^{\text {th }}$ tallest in the world (Figure 2). The crest width of the dam is $20 \mathrm{~m}$ with adequate flatter slopes on either side giving the width of 1,128 meters at the bottom. The length of the dam at the top is 575 meters, which is walled up in narrow gorge section of the river Bhagirathi. The dam body is filled with earth and rock material in well compacted layers. In order to retain the water, there is an impervious clay core wall on the dam body along its length, which is compacted to an unprecedented high density. In Tehri Dam this earthen core is centrally located with flatter sloping sections and is separated from the rock-material with well-graded filters on both sides.

Earth and rock-fill dams are naturally more earthquake resistant than concrete dams due to their large inertia, high degree of flexibility, and stability. In addition, a fine sand layer is provisioned on the upstream face of the core wall that, in the unlikely event of cracking of core, sand will be washed into the cracks to seal them. The dam is safeguarded with a chute spillway and four vertical shaft spillways to discharge the probable maximum flood of 15,540 cumecs, which is equivalent to 10,000 year return period flood. .

The Morning Glory type vertical shaft spillways

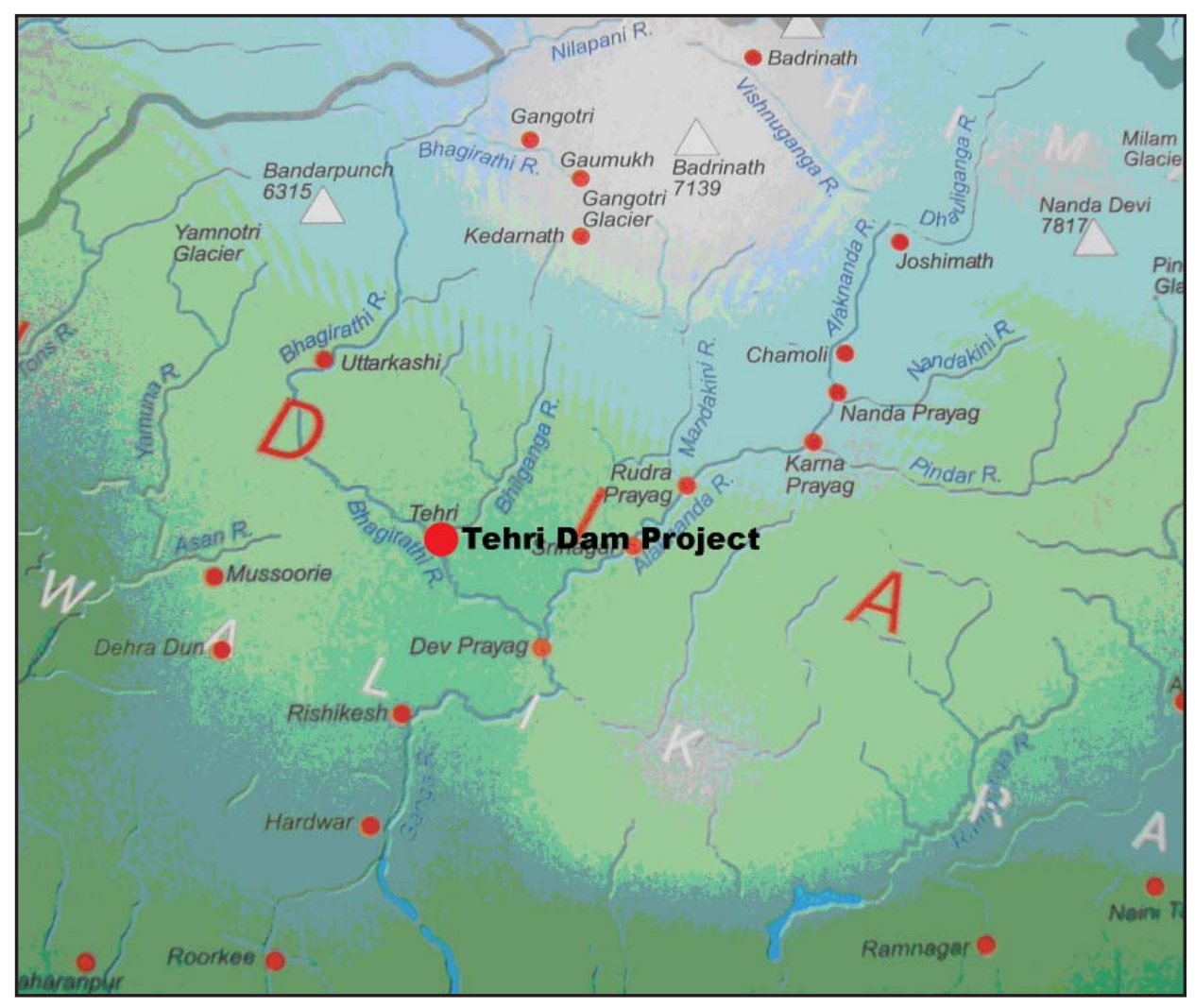

Figure 1. Index Map of Tehri Dam Project 
are unique from engineering perspective that is engineered at varied elevations in addition to normal chute spillway. In case of extreme events like a monsoon cloudburst, thesespillwayscan drain the incoming flood flow without hindrance. The Tehri Dam has an underground powerhouse with four units of Francis turbines of 250 MW each, threetransformers of 306 MVA capacity and a computerized control system. The generated power from Tehri Dam is being transmitted to the national grid system through $765 \mathrm{kV}$ transmission lines up to

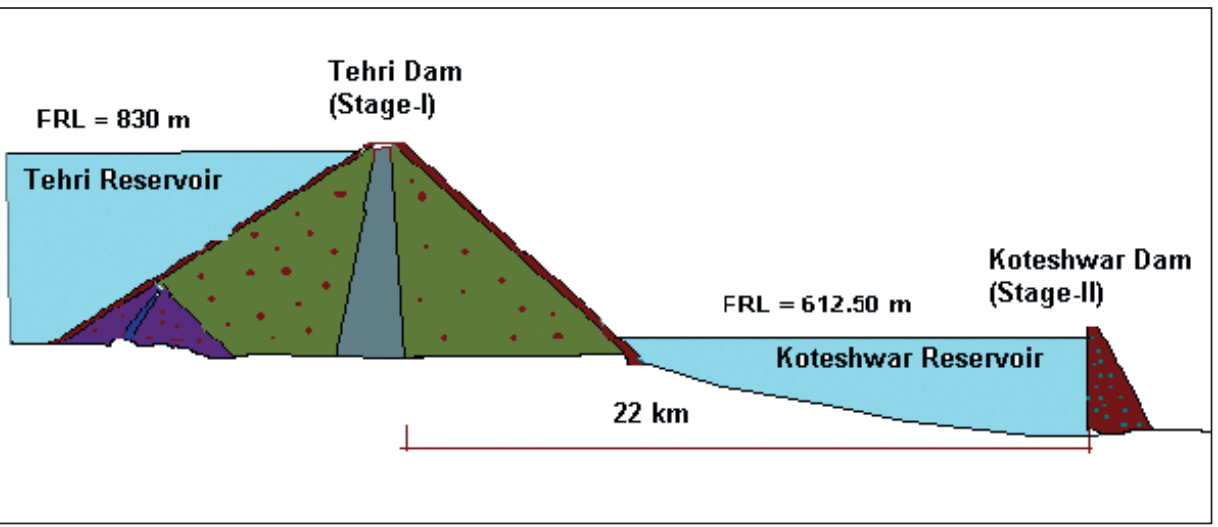

Figure 2. Sketch of Tehri and Koteshwar Dams Meerut.

For the additional safety of the earth and rock-fill dam, two inspection galleries are also equipped in the dam body to monitor the seepage and seismic activities during operation. In general, there should have not been any galleries in earth and rock-fill dams.

Despite the tremendous increase of total project cost from Rs 1.98 billion in 1976 to Rs 80 billion (Indian rupees), the first stage project of Tehri Dam is an engineering marvel of modern India, which has addressed successfully several engineering challenges and concerns towards development

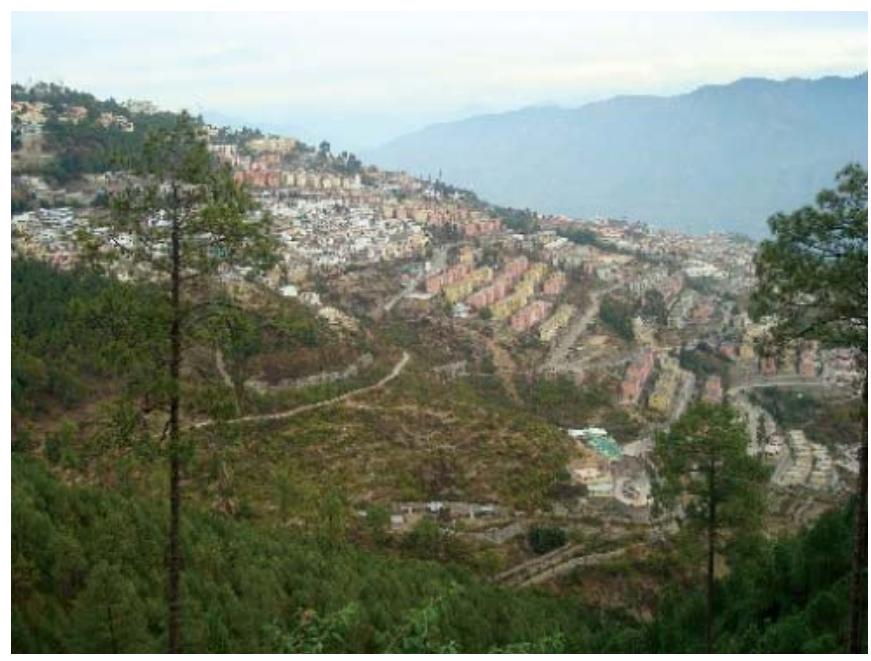

Photo 2. New Tehri Town

of high dams in Himalayan region.

The second stage of Tehri Hydropower Project is the Koteshwar Concrete Gravity Dam (Figure 2) with a height of $97 \mathrm{~m}$ designed to generate $400 \mathrm{MW}$ of electricity. An open powerhouse is planned to house four units of $100 \mathrm{MW}$ turbines at the toe of the dam itself with a switchyard at the downstream of the powerhouse. Spillways with four bays are designed for discharging 13,240 cumecs of maximum probable flood at the body of the concrete dam. All the civil works of the dam and powerhouse are in progress.

The third stage project is still under consideration. It aims to pump water from lower Koteshwar reservoir to

upper Tehri reservoir and generate power during peak hours of the day.

\section{Issues and Concerns}

One of the major issues of Tehri Dam implementation has been its safety aspect against seismic concerns in the Himalayan region. As the Main Central Thrust and Main Boundary Thrust lines traverse along the entire Himalayan region, the area is susceptible to high seismic risk. Over the past century several earthquake events have occurred in the region. Four of which were over eight on Richter Scale. During the design of the Tehri Project, a detailed

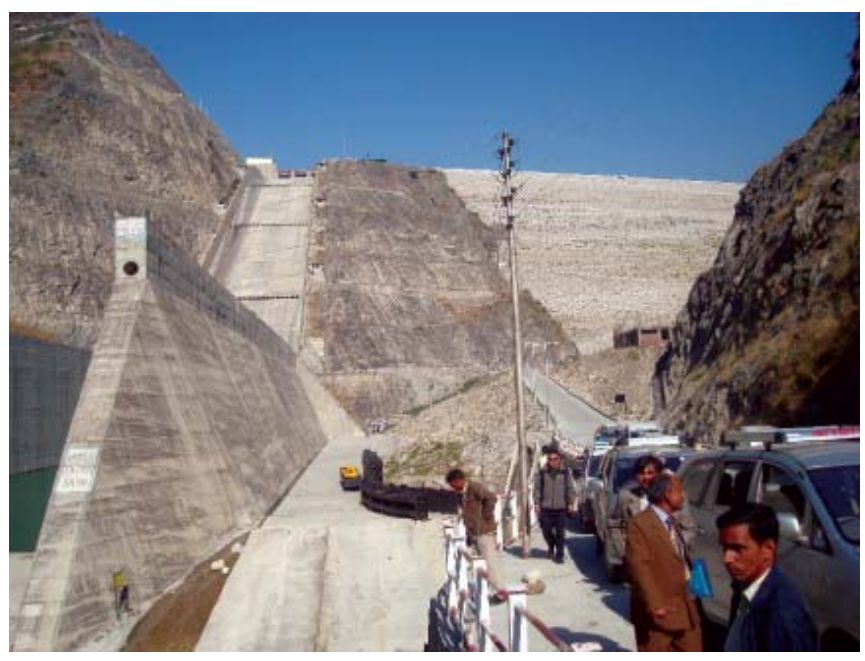

Photo 3. Downstream View of Tehri Dam

dynamic analysis of seismic risks was carried out at two renowned institutions, the University of Roorkee in India, and the Hydro Project Institute in Moscow. The analysis revealed that the designed rock-fill dam is safer due to its high flexibility and high damping characteristics in seismic accelerations. The dam slopes are provided significantly flatter at their upstream side. In addition to engineering responses to high seismic region, several precautions and counter measures are considered in the dam design to cope with the judgment on the writ petitions filed against the project implementation with respect to probable seismic accelerations during economic operation of the dam. One 
of the counter measures is specially treated sand layered in front of the clay core to fill any cracks if developed during operation. Three-Dimensional (3D) non-linear test was also carried out to evaluate the peak ground accelerations for maximum credible earthquakes of the Himalayan region and found safe from all dangers arising out of the seismicity. Further, the dam is reported to be safe for actual vertical acceleration of $1.36 \mathrm{~g}$ design and horizontal acceleration of $0.72 \mathrm{~g}$ both acting simultaneously.

Another concern of the Tehri Dam Project is the issue of adverse environment affect after project implementation, which is reported to be successfully addressed. There were three concerns raised by environmentalists and the local people. The first concern is related with the catchment area treatment, the second is for command area development, while the third is the maintenance of flora and fauna, including water quality. Of the total $6,920 \mathrm{~km}^{2}$ of the catchment area of Bhagirathi river about $3,560 \mathrm{~km}^{2}$ are snow covered and alpine blank areas and the rest are categorized as very high, high, medium and low erodibility classification depending upon the level of catchment degradation.

A comprehensive plan of catchment area treatment was prepared by the Government of India and implemented accordingly. It aimed to prevent soil erosion, minimize negative impacts of the project on the catchment, and regenerate vegetation in the catchment area and the water resources. There are no significant issues on the command area (irrigable farm land) development as the project aimed tostrengthen existingirrigation networks and command area in Uttar Pradesh. With respect to flora and fauna, the project planned activities to protect mahseer fish through artificial breeding, in addition to the creation of a new botanical garden of about 14 hectares near the Tehri reservoir.

The religious concerns of the Tehri Dam Project were also vital in addressing challenges to uninterrupted flow of Bhagirathi river. According to Hindu mythology, the Bhagirathi river is considered as the actual Ganga, which has to flow continuously from Gangotri to the Ganga Sagar. To address this religious issue a team of experts was constituted, which recommended providing uninterrupted flow of Bhagirathi across the dam body. As per the decisions of expert team, the THDC made provision of continuous flow of water from upstream to downstream which is known as Aviral Dhara. A piped intake with $40 \mathrm{~cm}$ diameter pipe allows 35 cusecs of Bhagirathi water to flow across the dam body and exit at the toe of the Tehri Dam, thus maintaining the sacredness of the Ganga river.

In addition to hydropower and irrigation benefits, Tehri Dam Project provides drinking water supply to Delhi, Uttar Pradesh and Uttarakhand. Despite the ample opportunities provided by the Tehri Dam on economic development of the country, there are still court cases pending against the construction of the Tehri Dam Project, but the Government of India has tried its best to demonstrate the human ability to respond on economic, environmental and social costs of building large dams.

\section{Rehabilitation and Resettlement}

ThemajorachievementinTehri Dam Projectisitssuccessful implementation of rehabilitation and resettlement plan for the involuntarily displaced populace including sentiments associated with heritage of old Tehri township. About 85,000 people were affected by this project. The rehabilitation plan was categorized into rural and urban rehabilitation and implemented accordingly. The urban rehabilitation relates with the rehabilitation of Tehri town which was established in 1803 by King Sudarshan Shah as the capital of Tehri-Garhwal. This age-old town is resettled in New Tehri town located on the right bank of the Tehri reservoir at an altitude of $1,600 \mathrm{~m}$. The New Tehri town is probably the most well planned and properly designed hill station since independent India. About 5,300 families are rehabilitated and resettled with modern urban facilities. The New Tehri town is a showpiece example of involuntary settlement plan of modern water projects of the world (Photo 2).

Many technical teams including the Three Georges Project of China have visited the resettlement and rehabilitation site of THDC. In addition, some families are also rehabilitated and resettled at Rishikesh and Dehradun, as per their option apart from compensation for their existing shops and other structures at the old Tehri town. The rural rehabilitation policy is different, which reveals that the rural displaced to be compensated through allotment of agriculture land of 2 acres or cash in lieu thereof and resettled in large blocks so that the fabric of their social life remains intact. The displaced or their representatives were involved to the extent possible in selecting the rehabilitation centers and the preference was given to the displaced for settlements at a particular location. Furthermore, the community facilities are provided at each of the rural rehabilitation centers for about 9,240 families if these did not exist at their earlier settlements. House construction assistance to the old Tehri town land owners, provisions of constructed flat at lower rates, goodwill grant to the shop keepers of old Tehri town, cash grant for advocates of old Tehri town, and grant to rural farmers for the purchase of seeds and fertilizers are additional facilities provided by the project to the affected people during their rehabilitation and resettlements. The noted environmental activists, Sundar Lal Buhuguna is also living in New Tehri Town in one of the resettlement houses provided by the project.

\section{Conclusions}

Standing near to one of the four units of 1,000 MW Tehri Dam powerhouse, one is inclined to think about Nepal's power generating system that hardly generates half of the capacity of this project. Really, Tehri resembles the similar geo-physical conditions like Mahabharat range of Nepal; which also has ample opportunities of developing similar projects like Tehri. On the one hand, Nepal's installed capacity of hydropower plants does not meet the everincreasing demand of the energy and, on the other hand, 
most of these power plants are based on run-of-river systems which operate at less than half capacity during lean season. The $114 \mathrm{~m}$ high Kulekhani Dam in Nepal can reserve only 85 million cubic meter of water and its normal reservoir level is decreasing day by day due to adverse hydrological conditions.

It is time to initiate a storage project in one of the snow-fed rivers, similar to the Tehri Dam, to overcome the existing load shedding and matching the future domestic demand and supply. Rather than planning to initiate similar hydropower plants, we are proud to declare the state of emergency in power sector and blame the past efforts in this regard. The declared National Electricity Crisis Mitigation Work Plan suggests building power plant from the solid waste disposal and installing wind mills. Will these steps match with the Government of Nepal's plan of generating 10,000 MW of electricity within ten years?

The lessons to be learned from the Tehri Dam Project is its rehabilitation and resettlement schemes that represents the government's commitment in addressing the issues of involuntary resettlement. About 5,300 urban families of old Tehri town are well rehabilitated in New Tehri town with modern urban facilities including hospital, educational institutions, and places for worships. In our Middle Marsyangdi Hydropower Project, where only 65 families are rehabilitated, the resettlement colony is not particularly different from that of adjacent rural settlements. The resettlement colony should have been different than that of other rural settlements. At last, it is worth to visit Tehri
Dam Project to study the issues and concerns of the project evolution to best learn lessons of its successful story.

Basistha Raj Adhikari is a Water Resources Engineer and holds an MSc degree in Hydraulic Engineering from the USSR (1984) and an MSc in Water Resources Engineering from Nepal (2001). He has more than 24 years of experience in the field of water resources planning and design, irrigation design and supervision, design of river training works, water induced disaster management and flood risk assessment. He has published several papers on irrigation management and other topics. Currently, he is working as Senior Divisional Engineer, Department of Water Induced Disaster Prevention, Nepal.

Corresponding address: basistha_adhikari@hotmail.com

\section{References}

Bandyopadhyay, J ., 2002, 'A critical look at the report of the World Commission on Dams in the context of the debate on large dams on the Himalayan rivers, Water Resources Development 18(1).

Dixit, A., 2002, Basic Water Science, Kathmandu: Nepal Water Conservation Foundation.

Subba, Bhim, 2001, Himalayan Waters, Kathmandu: Panos South Asia. URL: http:// thdc.nic.in 